\title{
Agricultural Land Conversion and the Influence of the Food Supply Chain
}

\author{
M Chairul Basrun Umanailo', Muhammad Bugis², Andries Lionardo³, Maryam Sangadji ${ }^{4}$, Esther \\ Kembauw $^{5}$ \\ ${ }^{1}$ Universitas Iqra Buru, Namlea, Maluku, Indonesia \\ 2,4,5 Universitas Pattimura, Ambon, Maluku, Indonesia \\ ${ }^{3}$ Universitas Sriwijaya, Palembang, Sumatera Selatan Indonesia \\ ${ }^{1}$ chairulbasrun@gmail.com, ${ }^{2}$ muh.bugis@gmail.com, ${ }^{3}$ andrieslionardo@ fisip.unsri.ac.id, ${ }^{4}$ maryam_sng@yahoo.co.id, \\ 5ekembauw@yahoo.co.id
}

\begin{abstract}
The phenomenon of changing the function of agricultural land in Namlea District becomes a problem when the amount of productive land decreases and has an impact on the availability of land for agricultural production and affects the supply chain of agricultural products to the community. The research was conducted to describe the conversion of agricultural land and its utilization in the Namlea subdistrict. The research site focuses on Namlea District Buru Regency with consideration of the availability of the number of agricultural lands that are less than other districts in the Buru Regency. The number of informants interviewed as many as 40 people consisting of landowners, farmers, business owners, and village apparatus. Analytical techniques used to follow the concept of Miles and Huberman where activities in the analysis of qualitative data are conducted interactively and continuously to find saturation in the data processing. The results showed that the reduction of farmland in Namlea district was due to the conversion of land for various activities including housing and development of the Trade Center. Besides, the use of converted land is caused by the system of personal ownership that is secured by the Government through the right to building or proprietary rights but has not fully set the long-term oriented land utilization pattern.
\end{abstract}

Keywords

Namlea; Conversion; Farmland; Village; Buru

Article Received: 10 August 2020, Revised: 25 October 2020, Accepted: 18 November 2020

\section{Introduction}

Namlea District is the capital of Buru Regency, consisting of 11 villages and 9 hamlets. The area of Namlea District is $226.55 \mathrm{Km}^{2}$ and the one with the largest population is in Buru Regency. According to the Central Bureau of Statistics, the population of Namlea District in 2018 is 34,326 people. This number continues to increase every year with a population growth rate of 6.26 percent (Mu'adi, Maksum, Hakim, \& Umanailo, 2020). With this population growth, there will automatically be an increase in the population in Namlea District (Banala, Agrawal, Kim, \& Scholz, 2010; Ghiffari, 2016; Nawawi et al., 2020; M. Chairul Basrun Umanailo, 2020b). The rapid increase in population resulted in the increasing need for land as a place of activity in Namlea District. This condition is followed by the sustainability of the supply chain of agricultural products to the community.

As a result of population growth and increased per capita consumption stimulated by an increase in household income, the need for food such as rice and horticultural food will continue to increase. To compensate for this increased need, production in the regions must increase proportionally to be adequate to maintain food sufficiency (W. Rumaolat, Lihi, Hamka, \& Umanailo, 2019; Wiwi Rumaolat, Dusra, et al., 2019; Wiwi Rumaolat, Lihi, Hamka, \& Umanailo, 2019). However, in Namlea Subdistrict, there has been a slowdown in growth due to reduced agriculture and a slowing rate of farm productivity growth plus the absence of technological breakthroughs that have been able to significantly increase productivity, thus affecting the availability of food stocks thus human resource management for the supply chain by itself will be disrupted (Elvis \& Ekta, 2011; Van Meijl, Van Rheenen, Tabeau, \& Eickhout, 2006).

In a situation where the Regional Government of Buru Regency is increasingly difficult to increase production due to the conversion of agricultural land to non-agricultural, this condition will exacerbate the regional food problem. Based on this, agricultural land conversion efforts have more important importance in supporting food security in Namlea District. Efforts to control agricultural land conversion are also needed to avoid various social, economic, and environmental problems as land conversion (Dalgaard, 2006).

Conversion of land functions or land conversion can be interpreted as a change in the function of the land area from its original function to other functions that can cause impacts or problems on the environment and land potential (M. Chairul Basrun Umanailo \& Ali, 2019) the expansion of the conversion of agricultural land to non-agricultural land with an indication that housing and shopping developments reach 15 percent each year.

In previous studies, Hidayat (2017) with the analysis of agricultural land conversion that occurs in Kertajati District, it shows that the conversion of agricultural land can have negative impacts in the form of social and economic losses for farmer households (Rachman, Hamiru, Umanailo, Yulismayanti, \& Harziko, 2019; Tahir \& Umanailo, 2019), Meanwhile, in his research, Riswandi found that agricultural land conversion occurs as a logical consequence of regional development. Agricultural land conversion often causes negative impacts, especially in the context of food security and farmers' socio-economic conditions (Hozdić, 2015; 
Romlah, Pratiwi, Indah, \& Umanailo, 2020). Hidayat found that the socio-economic impact of land conversion is a shift and diversification of farmers' livelihoods in agriculture and non-agriculture (Faust et al., 2018). The household income of farmers becomes increasing, constant, and decreasing depending on the type of new business they are engaged in. This research was conducted based on the preferences/attitudes of the landowners in converting (Rodríguez Eraso, Armenteras-Pascual, \& Alumbreros, 2013).

This paper aims to obtain a primary picture of the impact that occurs due to the increased conversion of agricultural land to non-agricultural in Namlea District, he is important given the large role of research results in shaping and influencing regional policies to limit land conversion to nonagriculture and organize human resource management. for the food supply chain in realizing community food security.

\section{Methods}

The research was conducted in Namlea District, Buru Regency. Determination of the location is done purposively (deliberately). The villages of Namlea, Marloso, and Lala were selected as research locations because most of the agricultural land in the locations were converted for housing development and development of long-lived crops (Kassen, 2018; Sumitro, Yuliadi, Kurniawansyah, Najamudin, \& Umanailo, 2020). The number of informants who will be interviewed is 30 people taken purposively with the consideration that the respondents are considered as related parties to achieve the research objectives. Informants are household farmers or owners of agricultural land converted for housing development and industrial crop development.

The data in this study were obtained from primary data sources and secondary data, with data collection techniques used through observation, interviews, questionnaires, and literature/ document studies. In the interview step, the researcher conducted in-depth interviews with related parties, namely farmer households, landowners, and gave questionnaires to the community in that location in response to land conversion. Researchers also looked for complementary information related to land use in Namlea District via the internet and literature studies using government documents/ archives related to agricultural land conversion policies and Food Security. The sample of data sources in qualitative research was selected purposively, invincible with the focus and research objectives (Shofwan et al., 2019), and prioritizing the emic perspective (Koh \& Wilcove, 2008; Muhasidah et al., 2019), meaning that he prioritizes views. informants, namely how they view and interpret the world from their stand (Djibu, Shofwan, \& Umanailo, 2019; Jannah, Widohardhono, Fatimah, Dewi, \& Umanailo, 2019; Rahmat, Gs, Djafri, Shofwan, \& Umanailo, 2019). This study uses data analysis techniques or techniques that use observation, in-depth interviews to obtain data on the standard of living conditions, before and after land conversion occurs and the impacts caused by the land conversion.

The analysis technique used in this research is qualitative data analysis following the concepts given by Miles and Huberman and Spradley (Ervina et al., 2019). Miles and Huberman, stated that the activity in interactive and continuous data analysis was continuous at each stage of the research so that it was complete, and the data was saturated. Activities in data analysis are data reduction (data reduction), data presentation (data display), drawing conclusions, or levers (concluding/ verification).

\section{Results}

activities are increasingly threatened due to the pressing need for housing and industrial development. The existence of agricultural land in the Namlea District. The vast land will further increase the hope of farmers to be able to live properly. Along with the increasing population, the existence of land, especially agricultural land, is becoming increasingly threatened due to the urgent need for more land. Meanwhile, the amount of available land has not increased (Meriam, 2019). The condition of agricultural land in Namlea District, as one of the important resources for the existence of farmers in carrying out agricultural activities, is increasingly threatened because of the need for housing and industrial development. The existence of agricultural land in the Namlea district. The vast land will further increase the hope of farmers to live properly (Menozzi, Fioravanzi, \& Donati, 2015). Along with the increasing population, the existence of land, especially agricultural land, is increasingly being threatened because of the need for more land. Meanwhile, the amount of available land has not increased (Bonin \& Lal, 2012; Garske, Heyl, Ekardt, Weber, \& Gradzka, 2020; Leclère et al., 2020).

Table 1. Percentage of Agricultural Land Area in Namlea

\begin{tabular}{|c|c|c|c|c|c|}
\hline \multirow{3}{*}{ Village } & \multicolumn{4}{|c|}{ District } & \multirow{3}{*}{$\begin{array}{l}\text { Percentage } \\
(\%) \\
2019\end{array}$} \\
\hline & $\begin{array}{l}\text { Administrative } \\
\text { area }\left(\mathbf{k m}^{2}\right)\end{array}$ & \multicolumn{2}{|c|}{$\begin{array}{l}\text { Agricultural } \\
\text { Area (ha) }\end{array}$} & Land & \\
\hline & 2019 & 2000 & 2010 & 2019 & \\
\hline Namlea & 12 & 115 & 71 & 42 & 2,85 \\
\hline Lala & 8 & 42 & 19 & 12 & 1,5 \\
\hline $\begin{array}{l}\text { Karang } \\
\text { Jaya }\end{array}$ & 2 & 36 & 28 & 19 & 9,5 \\
\hline Batuboi & 4 & 89 & 74 & 67 & 16,75 \\
\hline Jamilu & 4 & 41 & 35 & 29 & 7,25 \\
\hline Sanleko & 6 & 62 & 53 & 41 & 6,83 \\
\hline Siahoni & 2 & 48 & 36 & 23 & 11,5 \\
\hline
\end{tabular}

Source: Primary Data Processing, 2020

Table 1 shows that Namlea Village is an area that has the largest administrative area with a very small percentage of agricultural land, while Lala Village with an administrative area of around $8 \mathrm{Km} 2$ has 12 hectares of agricultural land which is the smallest amount compared to other villages. The supporting factor in the period of depletion of agricultural land is the distance between the village and the district capital. Namlea and Lala villages are the two closest locations where Namlea village is $0 \mathrm{Km}$ from the subdistrict centre and Lala is $3 \mathrm{Km}$ from Namlea town.

Land ownership begins with occupying an area by an indigenous community which is then called communal land (jointly owned land). In rural areas outside Java (de Souza et al., 2019), the land is recognized by unwritten customary law based on both ancestral and territorial relationships. In line with changes in socio-economic patterns in each community, land belonging to the common customary 
community is gradually controlled by community members through rotating cultivation. The individual ownership system then became known in the communal ownership system.

The definitions of "controlling" and "controlling" can be used in a physical sense, in a juridical sense as well as having a civil perspective and a public perspective (Lugato, Bampa, Panagos, Montanarella, \& Jones, 2014; Mukramin \& Sudarsono, 2019). Juridical control is based on rights, which are protected by law and generally give rights holders the authority to physically control the land they are entitled to. Juridical control which, even if it gives the authority to control the land that is physically entitled, is exercised by another party.

Table 2. Agricultural Land Ownership in Namlea District

\begin{tabular}{llll}
\hline Village & \multicolumn{3}{l}{ Agricultural Land Ownership Area (ha) } \\
& 2000 & 2010 & 2019 \\
\hline Namlea & 102 & 70 & 39 \\
Lala & 41 & 18 & 11 \\
Karang Jaya & 34 & 27 & 12 \\
Batuboi & 88 & 72 & 64 \\
Jamilu & 37 & 33 & 27 \\
Sanleko & 61 & 52 & 40 \\
Siahoni & 43 & 35 & 21
\end{tabular}

Source: Primary Data Processing, 2020

Table 2 shows the amount of land ownership that continues to decline from year to year, where the largest number occurs in Namlea Village with an average decline in ownership reaching 3-4 Ha per year. This means that agricultural land is reduced by selling to other parties. In the observations made by the researchers, most of the agricultural land was turned into offices and trading centres. Batuboy village is an area that has reduced ownership of agricultural land, and field results show that 80 percent of the villagers still own farmers and still maintain their farms to keep it processed. In other studies, land use can be mapped into several parts such as industry, housing, land, offices, and open land (Carvalho, Domingues, \& Horridge, 2017; Kopmann \& Rehdanz, 2013). The following shows general land use in the Namlea sub-district (Han, Yang, \& Song, 2015).

\section{Discussions}

Conversion of land functions or land conversion can be interpreted as a change in the function of the land area from its original function to other functions that may cause impacts or problems on the environment and land potential (Bugis et al., 2019; Cartwright-Finch \& Lavie, 2007; Uña Orejón, Ureta Tolsada, Uña Orejón, Maseda Garrido, \& Criado Jiménez, 2005). The conversion of land functions carried out by other parties usually takes place through the transfer of land ownership rights of farmers to other parties which is then followed by using the land for non-agricultural activities (Sekaran \& Bougie, 2014). The narrowing of land will have a direct impact on the volume of production that farmers do in the area. The following shows the land use in Namlea District (Demirbas, 2008; Xiong \& Tan, 2018).
Table 3 shows the land use carried out by the community in Namlea District with the largest number of housing sectors. Namlea Village as a village has the largest number of land uses for 586 hectares, while Siahoni Village is the village with the least amount of land use for housing (Garcia-Ulloa, Sloan, Pacheco, Ghazoul, \& Koh, 2012; Lawson et al., 2014). In developing land use in the Namlea sub-district as well as increasing the need for infrastructure development and trade centres, the use of open land will decrease, in the prediction that the development of the Namlea sub-district still requires around 500 hectares of land for development so that the existence of open land will continue to experience a reduction in the following years.

Table 3. Land Use in Namlea District

\begin{tabular}{llllll}
\hline Village & $\begin{array}{l}\text { Indu } \\
\text { stry } \\
\text { (ha) }\end{array}$ & $\begin{array}{l}\text { Housin } \\
\text { g(ha) }\end{array}$ & $\begin{array}{l}\text { Agricult } \\
\text { ure (ha) }\end{array}$ & $\begin{array}{l}\text { Offic } \\
\text { es } \\
\text { (ha) }\end{array}$ & $\begin{array}{l}\text { Open } \\
\text { Land } \\
\text { (Ha) }\end{array}$ \\
\hline Namlea & 14 & 586 & 42 & 16 & 542 \\
\hline Lala & 3 & 102 & 12 & 2 & 681 \\
Karang & 2 & 118 & 19 & 5 & 56 \\
Jaya & & & & & \\
\hline Batuboi & - & 89 & 67 & 1 & 243 \\
Jamilu & - & 91 & 29 & 1 & 279 \\
\hline Sanleko & - & 124 & 41 & 1 & 434 \\
Siahoni & - & 78 & 23 & 1 & 98 \\
\hline
\end{tabular}

Source: Primary Data Processing, 2020

Table 3 shows the land use carried out by the community in Namlea District with the largest number of housing sectors. Namlea Village as a village has the largest number of land uses for 586 hectares, while Siahoni Village is the village with the least amount of land use for housing (Bell, Cloy, \& Rees, 2014; Hannah et al., 2013). In developing land use in the Namlea sub-district as well as increasing the need for infrastructure development and trade centres, the use of open land will decrease, in the prediction that the development of the Namlea sub-district still requires around 500 hectares of land for development so that the existence of open land will continue to experience a reduction in the following years.

Rural and urban development planning requires careful calculation in land use, even the city becomes irregular due to uncontrolled land use regulations and regulations since the first construction was carried out (Carlson et al., 2012; Han et al., 2015), as the author found the conversion pattern that occurred in Namlea District (Wei, Shao, Gale, \& Li, 2014).

Table 4. The Pattern of Agricultural Land Conversion in Namlea District

\begin{tabular}{llllllll}
\hline Village & \multicolumn{6}{c}{ Open land to developed land } & \multicolumn{2}{l}{$\begin{array}{l}\text { Agricultural } \\
\text { developed land }\end{array}$} & land & to \\
& $\begin{array}{l}\text { Industry } \\
\text { (ha) }\end{array}$ & $\begin{array}{l}\text { Housing } \\
\text { (ha) }\end{array}$ & $\begin{array}{l}\text { Offices } \\
\text { (ha) }\end{array}$ & $\begin{array}{l}\text { Industry } \\
\text { (ha) }\end{array}$ & $\begin{array}{l}\text { Housing } \\
\text { (ha) }\end{array}$ & $\begin{array}{l}\text { Offices } \\
\text { (ha) }\end{array}$ \\
\hline Namlea & 10 & 550 & 14 & 4 & 36 & 2 \\
\hline Lala & 3 & 98 & 1 & - & 4 & 1 \\
\hline $\begin{array}{l}\text { Karang } \\
\text { Jaya }\end{array}$ & 2 & 103 & 4 & - & 15 & 1 \\
\hline Batuboi & - & 78 & 1 & - & 11 & - \\
\hline Jamilu & - & 89 & 1 & - & 2 & - \\
\hline Sanleko & - & 119 & 1 & - & 5 & - \\
Siahoni & - & 68 & 1 & - & 10 & - \\
\hline
\end{tabular}

Source: Primary Data Processing, 2020 
The area of agricultural land in Namlea district is quite large, the influence of the development of the city centre has resulted in areas such as the villages of Lala, Namlea, and Karang Jaya targeting communities to carry out function changes such as building shelters and trade centres. The reduction in agricultural land that has occurred in several villages due to community needs is not a result of a decrease in soil quality but rather an economic calculation for carrying out daily activities related to meeting household needs. Ownership of agricultural land in the Namlea subdistrict is divided into several parts, including lineage ownership, ownership that comes from business results and ownership that comes from profits. Of the three factors that most dominate the change in utilization are the results of the businesses where people prefer to invest in their land. Agricultural land turned into a centre of trade and shopping as a result of the needs and trends of the people who need space for economic activity. Apart from that, land investment is also considered profitable and has easy implementation (Popp et al., 2014; Zhong, Huang, Zhang, \& Wang, 2011).

The use of land which is divided into the industry, housing, agriculture, offices, and open land becomes an illustration of the land mapping in Namlea District. In its use, the community dominates the use of land in housing as a basic need that must be met (Xu, Polley, Hofmockel, \& Wilsey, 2017; Yusuf, Umanailo, Putri, Ely, \& Darma, 2019). Besides, land that is easier and cheaper to convert its agricultural land at an affordable price. The following shows the impact of the conversion that occurred in the Namlea sub-district.

Table 5. The Impact of Agricultural Land Conversion on Farmers in Namlea District

\begin{tabular}{|c|c|c|}
\hline Village & Economy & Social \\
\hline Namlea & $\begin{array}{l}\text { The income of farmers } \\
\text { is decreasing, the price } \\
\text { of agricultural } \\
\text { products is getting } \\
\text { more expensive, the } \\
\text { selling price of land } \\
\text { increases, the job } \\
\text { opportunities in the } \\
\text { agricultural sector are } \\
\text { reduced. }\end{array}$ & $\begin{array}{l}\text { There has been a } \\
\text { change in the } \\
\text { livelihood of } \\
\text { farmers, an increase } \\
\text { in the number of } \\
\text { people from outside } \\
\text { the village, the } \\
\text { development of } \\
\text { agrarian conflicts }\end{array}$ \\
\hline Jamilu & $\begin{array}{l}\text { The number of } \\
\text { farmers is decreasing }\end{array}$ & $\begin{array}{l}\text { The shift in } \\
\text { livelihoods and } \\
\text { orientation of } \\
\text { farmer households }\end{array}$ \\
\hline Sanleko & $\begin{array}{l}\text { The number of } \\
\text { farmers is decreasing }\end{array}$ & $\begin{array}{l}\text { The shift in } \\
\text { livelihoods and } \\
\text { orientation of } \\
\text { farmer households }\end{array}$ \\
\hline $\begin{array}{l}\text { Karang } \\
\text { Jaya }\end{array}$ & $\begin{array}{l}\text { The amount of land } \\
\text { decreases due to the } \\
\text { construction of } \\
\text { people's houses } \\
\text { followed by a } \\
\text { reduction in workers } \\
\text { in the agricultural } \\
\text { sector. }\end{array}$ & $\begin{array}{l}\text { The shift in } \\
\text { livelihoods and } \\
\text { orientation of } \\
\text { farmer households }\end{array}$ \\
\hline Siahoni & $\begin{array}{l}\text { The number of } \\
\text { farmers is decreasing }\end{array}$ & $\begin{array}{l}\text { The shift } \\
\text { livelihoods }\end{array}$ \\
\hline
\end{tabular}

$\begin{array}{lll}\text { Batuboy } & \begin{array}{l}\text { The number of of } \\ \text { farmers is decreasing } \\ \text { farmer households } \\ \text { The shift in } \\ \text { livelihoods and } \\ \text { orientation of } \\ \text { farmer households }\end{array} \\ \text { Lala } & \begin{array}{l}\text { The number of } \\ \text { farmers has decreased } \\ \text { followed by a decrease } \\ \text { in agricultural } \\ \text { production. }\end{array} & \begin{array}{l}\text { Indigenous people } \\ \text { village } \\ \text { to work in the } \\ \text { service sector }\end{array}\end{array}$

Source: Primary Data Processing, 2020

Land use is closely related to ownership where ownership is governed by building rights, property rights, use rights. Of the three rights attached to land status, building rights are the main choice for communities to invest in and change land functions as a result of protection from the country (Strassburg et al., 2014). Table 5 shows the impacts caused by land conversion carried out by the community in the Namlea sub-district. The economic impact shows a reduction in income and an increase in the selling price of land, while for the social impact there is a change in the orientation of livelihoods by farmer households.

Theoretically, land conversion usually takes place through the transfer of land ownership rights of

farmers to other parties which is then followed by using the land for non-agricultural activities narrowing of land (Menozzi et al., 2015). Narrowing of land will have a direct impact on the volume of rice production carried out by farmers in the region. This narrowing of land will also have an impact on the economic conditions of farmers

\section{Conclusion}

In general, the condition of agricultural land in the Namlea sub-district has a development in use, where land conversion is more directed towards investment outside of agriculture, conditions like this greatly affect the availability of foodstuffs and the food supply chain. Some of the methods used are selling or renting with the motive of making a profit on the land. The land ownership in Namlea District is generally private land and customary land. The state guarantees ownership in the form of property rights, building rights, and usage rights, these three rights open up investment opportunities outside the agricultural sector. Land use is dominated by the housing sector due to population growth and urban development which causes the need for housing to increase.

\section{Acknowledgement}

Our gratitude goes to the Head of LL2Dikti Region 12 for the support to researchers, to LPPM Sriwijaya University, LPPM Pattimura University and also LPPM Iqra Buru University for the assistance of facilities and infrastructure during this research. 


\section{References}

[1] Banala, S. K., Agrawal, S. K., Kim, S. H., \& Scholz, J. P. (2010). Novel gait adaptation and neuromotor training results using an active leg exoskeleton. IEEE/ASME Transactions on Mechatronics.

https://doi.org/10.1109/TMECH.2010.204 1245

[2] Bell, M. J., Cloy, J. M., \& Rees, R. M. (2014). The true extent of agriculture's contribution to national greenhouse gas emissions. Environmental Science and Policy.

https://doi.org/10.1016/j.envsci.2014.02.00 1

[3] Bonin, C., \& Lal, R. (2012). Agronomic and ecological implications of biofuels. In Advances in Agronomy. https://doi.org/10.1016/B978-0-12394278-4.00001-5

[4] Bugis, R., Assagaf, S. A., Polanunu, A., Ningkeula, E. S., Fesanrey, W., Ismail, L., \& Chairul, M. (2019). Workers in the Namlea Market. International Journal Of Scientific \& Technology Research, 8(9), 2044-2047.

[5] Carlson, K. M., Curran, L. M., Ratnasari, D., Pittman, A. M., Soares-Filho, B. S., Asner, G. P., ... Rodrigues, H. O. (2012). Committed carbon emissions, deforestation, and community land conversion from oil palm plantation expansion in West Kalimantan, Indonesia. Proceedings of the National Academy of Sciences of the United States of America. https://doi.org/10.1073/pnas.1200452109

[6] Cartwright-Finch, U., \& Lavie, N. (2007). The role of perceptual load in inattentional blindness.

Cognition. https://doi.org/10.1016/j.cognition.2006.01 .002

[7] Carvalho, T. S., Domingues, E. P., \& Horridge, J. M. (2017). Controlling deforestation in the Brazilian Amazon: Regional economic impacts and land-use change. Land Use Policy. https://doi.org/10.1016/j.landusepol.2017. 03.001

[8] Dalgaard, T. (2006). Looking at Biofuels and Bioenergy. Science. https://doi.org/10.1126/science.312.5781.1 $743 b$

[9] de Souza, D. M., Kappler, G., Bueno, A. B., Silva, J. L. da, Modolo, R. C. E., Moraes, C. A. M., ... Brehm, F. A. (2019). From farm to land: Characteristics of biochar for agricultural purposes. European Biomass Conference and Exhibition Proceedings.

[10] Demirbas, A. (2008). Biofuels sources, biofuel policy, biofuel economy and global biofuel projections. Energy Conversion and Management. https://doi.org/10.1016/j.enconman.2008.0 2.020

[11] Djibu, R., Shofwan, I., \& Umanailo, M. C. B. (2019). Development of Andragogical Learning Model to Improve Life Skill for Teenagers Who Drop Out of School in Gorontalo City. International Journal Of Scientific \& Technology Research Volume, 8(10).

[12] Elvis, A. M., \& Ekta, J. S. (2011). Ozone therapy: A clinical review. Journal of Natural Science, Biology and Medicine. https://doi.org/10.4103/0976-9668.82319

[13] Garcia-Ulloa, J., Sloan, S., Pacheco, P., Ghazoul, J., \& Koh, L. P. (2012). Lowering environmental costs of oil-palm expansion in Colombia. Conservation Letters. https://doi.org/10.1111/j.1755263X.2012.00254.x

[14] Garske, B., Heyl, K., Ekardt, F., Weber, L. M., \& Gradzka, W. (2020). Challenges of food waste governance: An assessment of European legislation on food waste and recommendations for improvement by economic instruments. Land. https://doi.org/10.3390/land9070231

[15] Ghiffari, R. A. (2016). Development of Eucalyptus Oil Agro-industries in Kabupaten Buru. Procedia - Social and Behavioral 
https://doi.org/10.1016/j.sbspro.2016.06.1 50

[16] Han, H., Yang, C., \& Song, J. (2015). Scenario simulation and the prediction of land use and land cover change in Beijing, China. Sustainability (Switzerland). https://doi.org/10.3390/su7044260

[17] Hozdić, E. (2015). Smart factory for industry 4.0: A review. International Journal of Modern Manufacturing Technologies.

[18] Jannah, M., Widohardhono, R., Fatimah, F., Dewi, D. K., \& Umanailo, M. C. B. (2019). Managing cognitive anxiety through expressive writing in studentathletes. International Journal of Scientific and Technology Research, 8(10).

[19] Kassen, M. (2018). Adopting and managing open data: Stakeholder perspectives, challenges and policy recommendations. Aslib Journal of Information Management, 70(5), 518-537. https://doi.org/10.1108/AJIM-11-20170250

[20] Koh, L. P., \& Wilcove, D. S. (2008). Is oil palm agriculture really destroying tropical biodiversity? Conservation Letters. https://doi.org/10.1111/j.1755-

263x.2008.00011.x

[21] Kopmann, A., \& Rehdanz, K. (2013). A human well-being approach for assessing the value of natural land areas. Ecological Economics.

https://doi.org/10.1016/j.ecolecon.2013.04. 014

[22] Lawson, S., Blundell, A., Cabarle, B., Basik, N., Jenkins, M., \& Canby, K. (2014). Consumer Goods and Deforestation: An Analysis of the Extent and Nature of Illegality in Forest Conversion for Agriculture and Timber Plantations. Forest Trends Report.

[23] Leclère, D., Obersteiner, M., Barrett, M., Butchart, S. H. M., Chaudhary, A., De Palma, A., ... Young, L. (2020). Bending the curve of terrestrial biodiversity needs an integrated strategy. Nature. https://doi.org/10.1038/s41586-020-2705$\mathrm{y}$

[24] Menozzi, D., Fioravanzi, M., \& Donati, M. (2015). Farmer's motivation to adopt sustainable agricultural practices. BioBased and Applied Economics. https://doi.org/10.13128/BAE-14776

[25] Meriam, A. (2019). Analisis Pengaruh Firm Size, Risiko Keuangan, \& Profitabilitas Terhadap Risiko Bisnis pada Perusahaan Sektor Makanan \& Minuman di Bursa Efek Indonesia. Jurnal Dialektika, 4(2), 39-49. https://doi.org/10.36636/dialektika.v4i2.34 8

[26] Mu'adi, S., Maksum, A., Hakim, M. L., \& Umanailo, M. C. B. (2020). Transfer of function agricultural land. Proceedings of the International Conference on Industrial Engineering and Operations Management, 0(March), 2568-2574.

[27] Muhasidah, M., Nasrullah, N., Yusuf, M. M., Jaya, N., Laubo, N., Angriani, S., ... Farida, N. N. (2019). Healthy Food with Children Learning Achievements at Makassar City Elementary School. International Journal of Scientific \& Technology Research Volume, 8(10), 1875-1882. Retrieved from http://www.ijstr.org/research-paperpublishing.php?month=oct2019

[28] Mukramin, S., \& Sudarsono, S. (2019). REVOLUSI Hijau Pada Perubahan Sosial Komunitas Tani (Studi Alat Produksi di Desa Tebongeano, Kecamatan Lambai, Kabupaten Kolaka Utara). Walasuji : Jurnal Sejarah Dan Budaya, 10(1), 47-56. https://doi.org/10.36869/wjsb.v10i1.38

[29] Nawawi, M., Ali, A., Irawan, B., Ahmad, B., Mukramin, S., Marsuki, N. R., ... Kaya, I. R. G. (2020). The village kalesang program as a poverty alleviation community. International Journal of Scientific and Technology Research, 9(3), 3103-3107.

[30] Popp, A., Humpenöder, F., Weindl, I., Bodirsky, B. L., Bonsch, M., LotzeCampen, H., ... Dietrich, J. P. (2014). 
Land-use protection for climate change mitigation. Nature Climate Change. https://doi.org/10.1038/nclimate2444

[31] Rachman, S., Hamiru, H., Umanailo, M. C. B., Yulismayanti, Y., \& Harziko, H. (2019). Semiotic Analysis of Indigenous Fashion in The Island of Buru. International Journal Of Scientific \& Technology Research, 8(8), 1515-1519.

[32] Rahmat, A., Gs, A. D., Djafri, N., Shofwan, I., \& Umanailo, M. C. B. (2019). The Influence of Family Leadership towards Adolescent Social Values in the City of Gorontalo. International Journal Of Scientific \& Technology Research, 8(10).

[33] Rodríguez Eraso, N., Armenteras-Pascual, D., \& Alumbreros, J. R. (2013). Land use and land cover change in the Colombian Andes: Dynamics and future scenarios. Journal of Land Use Science. https://doi.org/10.1080/1747423X.2011.65 0228

[34] Romlah, S. N., Pratiwi, R. D., Indah, F. P. S., \& Umanailo, M. C. B. (2020). Qualitative study factors triggering gay characteristics in gay groups in Palmerah District West Jakarta. Proceedings of the International Conference on Industrial Engineering and Operations Management.

[35] Rumaolat, W., Lihi, M., Hamka, H., \& Umanailo, M. C. B. (2019). Factors associated with mother in doing diarrhea prevention efforts in Toddler Village Iha work area community health center Amahai. International Journal of Scientific and Technology Research, 8(10).

[36] Rumaolat, Wiwi, Dusra, E., Tunny, I. S., Malisngorar, M. S. J., Cahyawati, S., \& Umanailo, M. C. B. (2019). Relationship Diet and Regulate Blood Sugar in the Elderly with DM Type Ii in Waimital Village , Kairatu District , West Seram Regency. International Journal Of Scientific \& Technology Research, 8(10).

[37] Rumaolat, Wiwi, Lihi, M., Hamka, H., \& Umanailo, M. C. B. (2019). Factors Associated With Mother in Doing Diarrhea Prevention Efforts in Toddler
Village Iha Work Area Community Health Center Amahai. International Journal Of Scientific \& Technology Research Volume, 8(10).

[38] Sekaran, U., \& Bougie, R. (2014). Research Method For Business. Encyclopedia of Quality of Life and WellBeing Research.

[39] Shofwan, I., Raharjo, T. J., Achmad Rifai, R. C., Fakhruddin, F., Sutarto, J., Utsman, U., ... Umanailo, M. C. B. (2019). Nonformal learning strategy based on tahfidz and character in the primary school. International Journal of Scientific and Technology Research, 8(10).

[40] Strassburg, B. B. N., Latawiec, A. E., Barioni, L. G., Nobre, C. A., da Silva, V. P., Valentim, J. F., ... Assad, E. D. (2014). When enough should be enough: Improving the use of current agricultural lands could meet production demands and spare natural habitats in Brazil. Global Environmental Change. https://doi.org/10.1016/j.gloenvcha.2014.0 6.001

[41] Tahir, S. Z. A. Bin, \& Umanailo, M. C. B. (2019). Consumption Culture of Namlea Communities. Proceedings of the International Conference on Industrial Engineering and Operations Management Riyadh, Saudi Arabia, 974-978. Riyadh, Saudi Arabia: IEOM Society International.

[42] Umanailo, M. Chairul Basrun. (2020b). The energy in the context of social. Proceedings of the International Conference on Industrial Engineering and Operations Management, 0(March), 25032508.

[43] Umanailo, M. Chairul Basrun, \& Ali, A. (2019). The limited use of information technology on services and learning at Iqra Buru University. Proceedings of the International Conference on Industrial Engineering and Operations Management, 1133-1139. Toronto, Canada.

[44] Umanailo, M Chairul Basrun. (2020). Dominance of Economic Capital. 
International Journal Of Scientific \& Technology Research Volume, 9(01), 1-4.

[45] Uña Orejón, R., Ureta Tolsada, P., Uña Orejón, S., Maseda Garrido, E., \& Criado Jiménez, A. (2005). Ventilación mecánica no invasiva. Revista Espanola de Anestesiologia y Reanimacion. https://doi.org/10.1016/s03002896(15)31129-7

[46] Van Meijl, H., Van Rheenen, T., Tabeau, A., \& Eickhout, B. (2006). The impact of different policy environments on agricultural land use in Europe. Agriculture, Ecosystems and Environment. https://doi.org/10.1016/j.agee.2005.11.006

[47] Wei, X., Shao, M., Gale, W., \& Li, L. (2014). Global pattern of soil carbon losses due to the conversion of forests to agricultural land. Scientific Reports. https://doi.org/10.1038/srep04062

[48] Xiong, C., \& Tan, R. (2018). Will the land supply structure affect the urban expansion form? Habitat International. https://doi.org/10.1016/j.habitatint.2018.04 .003

[49] Xu, X., Polley, H. W., Hofmockel, K., \& Wilsey, B. J. (2017). Species composition but not diversity explains recovery from the 2011 drought in Texas grasslands. Ecosphere.

https://doi.org/10.1002/ecs2.1704

[50] Yusuf, S., Umanailo, M. C. B., Putri, R. N., Ely, D. Q. M., \& Darma, D. (2019). Village Institution Relations in the Utilization of Village Funds in Namlea District. International Journal Of Scientific \& Technology Research, 8(8).

[51] Zhong, T. Y., Huang, X. J., Zhang, X. Y., \& Wang, K. (2011). Temporal and spatial variability of agricultural land loss in relation to policy and accessibility in a low hilly region of southeast China. Land Use Policy.

https://doi.org/10.1016/j.landusepol.2011. 01.004 